\title{
PENGARUH PEMBELAJARAN OUTDOOR TERHADAP PENGETAHUAN, DAN SIKAP PELESTARIAN LINGKUNGAN MAHASISWA S1 PENDIDIKAN GEOGRAFI UNIVERSITAS KANJURUHAN MALANG
}

\author{
Agus Purnomo \\ Universitas Negeri Malang \\ Email:purnomo.agus88@gmail.com
}

\begin{abstract}
Abstrak: Tujuan penelitian ini yaitu: (1) Mengetahui pengaruh pembelajaran outdoor terhadap pengetahuan pelestarian lingkungan mahasiswa S1 Pendidikan Geografi Universitas Kanjuruhan Malang, (2) Mengetahui pengaruh pembelajaran outdoor terhadap sikap pelestarian lingkungan mahasiswa S1 Pendidikan Geografi Universitas Kanjuruhan Malang. Penelitian ini termasuk jenis eksperimen yang bertujuan untuk menilai pengaruh suatu perlakuan pendidikan terhadap sikap dan perilaku mahasiswa sebelum dan sesudah diberi tindakan. Berdasarkan uji homogenitas kemampuan kognitif peserta didik didapatkan kesimpulan bahwa karakter subjek penelitian homogen jadi penentuan kelas eksperimen dan kontrol dapat dilakukan dengan metode random. Hasil penelitian ini menunjukkan penerapan pembelajaran outdoor dapat meningkatkan pengetahuan mereka tentang pelestarian lingkungan, hal ini ditandai dengan hasil uji beda antara kelas kontrol dan eksperimen yang menunjukkan beda yang signifikan. Tetapi itu tidak menjamin sikap mereka akan konsisten dengan pengetahuan yang dimiliki. Jadi untuk menyikapi hal tersebut, dalam upaya meningkatkan pemahaman peserta didik pada pelestarian lingkungan maka tidak hanya dari satu pihak saja, yaitu lembaga pendidikan. Perlu adanya kerja sama dengan pihak-pihak yang langsung berhubungan dengan mereka, seperti orang tua, masyarakat sekitar, sampai petugas kebersihan agar terbentuk masyarakat yang paham terhadap pelestarian lingkungan demi terwujudnya pembangunan yang berkelanjutan.
\end{abstract}

Kata Kunci: Pengetahuan, Sikap, Perilaku dan Pembelajaran Outdoor

\section{PENDAHULUAN}

Penanaman pondasi pembelajaran

lingkungan seharusnya dilakukan sejak

dini, agar peserta didik memiliki

pemahaman tentang lingkungan.

Pembelajaran lingkungan diharapkan

mampu mendidik peserta didik agar

berperilaku peduli terhadap lingkungan.

Contoh-contoh dalam memelihara

lingkungan dapat diberikan oleh guru sehingga peserta didik dapat mencintai lingkungan, misalnya memberi pelajaran tentang cara membuang sampah pada tempatnya, mengajak peserta didik melihat keindahan taman laut dan keanekaragaman biota laut, serta membawa peserta didik melihat sistem pengelolaan air minum yang berasal dari air sungai. Jika pengetahuan dan sikap 
Agus Purnomo. Pengaruh Pembelajaran Outdoor Terhadap Pengetahuan,

Dan Sikap Pelestarian Lingkungan Mahasiswa S1 Pendidikan Geografi Universitas Kanjuruhan Malang

peduli terhadap lingkungan dapat

berbasis ekologi perairan melalui ditanamkan sedini mungkin, dapat diharapkan ketika mereka sudah remaja dan dewasa bekal pengetahuan, sikap, dan perilaku dalam dirinya terhadap lingkungan akan berdampak positif.

Salah satu model pembelajaran yang dapat menanamkan pengetahuan, sikap dan perilaku peduli lingkungan adalah pembelajaran di luar kelas. Dumouchel (2003) menyatakan bahwa pembelajaran di luar kelas (outdoor) bertujuan untuk meningkatkan kesadaran peserta didik terhadap: 1) diri sendiri melalui masalah sehari-hari yang ditemui, 2) orang lain melalui permasalahan kelompok dan dalam pengambilan keputusan, 3) lingkungan melalui pengamatan secara langsung. Melalui pembelajaran berbasis outdoor, guru dapat menumbuhkan literasi lingkungan bagi peserta didik dan membekali peserta didik dengan pengetahuan, keterampilan, dan sikap peduli terhadap lingkungan.

Keunggulan dari pembelajaran out door dalam permasalahan lingkungan terekam dari beberapa penelitian para ahli, antara lain Tumisem (2007) dalam menemukan bahwa pelaksanaan program pembelajaran lingkungan di luar kelas kegiatan pramuka di SD mampu meningkatkan literasi lingkungan sebesar 47\% dan mengubah sikap peserta didik terhadap lingkungan perairan sebesar 52\%. Dan pada American Institutes for Research (2005) dalam penelitiannya menunjukkan bahwa peserta didik yang berpartisipasi dalam program pembelajaran outdoor secara signifikan mempunyai kepedulian yang lebih besar terhadap lingkungan, dibandingkan dengan peserta didik yang tidak mengikuti program tersebut.

Menurut Wurdinger dalam Herry (2009), "pendidikan di alam akan dapat dirasakan langsung manfaatnya oleh setiap individu berdasarkan kemampuan yang ia miliki". Sementara itu penelitian yang dilakukan oleh Kraft dalam Herry (2009) terhadap generasi muda di Amerika menyatakan "metodologi pendidikan dan latihan yang sangat efektif manfaatnya adalah menggunakan alam sebagai media untuk pengetahuan”.

Pembelajaran outdoor sudah menjadi program kegiatan sekolah di luar negeri, seperti di Kanada, USA, Jerman, Malaysia, Singapura dan program tersebut dinamakan "Outward Bound". 
Outward Bound masuk ke Indonesia tahun 1990 dan dinamakan Outward Bound Indonesia, yang memulai kegiatan pelatihannya tahun 1991. Pusat pelatihan Outward Bound ini adalah di Jatiluhur, Purwakarta, Jawa Barat.

Kegiatan Outdoor penerapannya melalui Experiental Learning 'Belajar dari Pengalaman'. Experiental Learning adalah proses belajar mengajar yang mengutamakan respon terhadap dan refleksi pada pengalaman konkret. Hal itu mencakup emosi, imajinasi, fisik maupun intelek yang bersifat holistik (bulat dan menyeluruh), Hopkins \& Putnam (1993).

Kemudian Johnson (1991) menjelaskan lebih jauh bahwa Experiental Learning pada dasarnya dimulai dengan perumusan suatu action theory. Suatu Action Theory pada dasarnya menyatakan tindakan-tindakan atau aksi-aksi, kegiatan-kegiatan apa yang dibutuhkan untuk mencapai suatu konsekuensi yang diharapkan dalam situasi tertentu (Johnson \& Johnson, 1991). Terdapat banyak model belajar dari pengalaman ini yang mempunyai landasan dan anggapan dasar yang berbeda-beda, tetapi tidak mengubah inti pengertian Experiental Learning.

Lewin dalam Johnson \& Johnson, (1991) berpendapat bahwa dari belajar, berubah dan tumbuh akan berjalan mulus dengan proses terpadu yang dimulai dengan pengalaman dari sana-sini diikuti dengan pengalaman data dan observasi tentang pengalaman. Data kemudian dianalisis dan kesimpulan dari analisis ini dijadikan umpan balik dan dipergunakan untuk mengubah perilaku individu dan untuk memilih pengalaman baru. Belajar pada dasarnya mengikuti siklus empat tahap. Pengalaman konkrit seketika merupakan dasar dari observasi dan refleksi. Observasi dicernakan kepada "teori" perorangan yang kemudian dapat menarik kesimpulan untuk tindakan yang baru. Implikasi atau hipotesis ini menjadi petunjuk tindakan untuk menciptakan yang baru.

Untuk menghasilkan manusia yang peduli terhadap lingkungan dan memiliki kemampuan menanamkan pemahaman peduli terhadap lingkungan bagi peserta didik, Program Studi Pendidikan Geografi Fakultas Keguruan dan Ilmu Pembelajaran (FKIP) Universitas Kanjuruhan Malang sebagai lembaga penghasil guru perlu mendidik mahasiswanya agar dapat mengajarkan pembelajaran lingkungan dan menanamkan sikap peduli terhadap lingkungan. Melalui mata kuliah Geografi Lingkungan, mereka diberi bekal 
Agus Purnomo. Pengaruh Pembelajaran Outdoor Terhadap Pengetahuan,

Dan Sikap Pelestarian Lingkungan Mahasiswa S1 Pendidikan Geografi Universitas Kanjuruhan Malang

pengetahuan tentang konsep dasar lingkungan. Untuk dapat mengajarkan pembelajaran lingkungan pada siswa, mereka dibekali dalam mata kuliah Perencanaan Pembelajaran. Walaupun sudah mengikuti kedua mata kuliah ini, kenyataannya masih terdapat kesulitan dalam merencanakan pembelajaran. Hal ini disebabkan oleh kekurangmampuan mereka dalam memilih metode pembelajaran yang cocok untuk menanamkan pemahaman pelestarian lingkungan. Di samping itu, perkuliahan Geografi Lingkungan yang berjalan selama ini kurang menekankan pada aspek sikap dan cara menanamkan sikap peduli lingkungan. Permasalahan ini dapat diatasi dengan membekali mereka dengan pengalaman belajar yang dapat menanamkan sikap dan perilaku peduli terhadap lingkungan yang diintegrasikan dalam perkuliahan, yaitu pembelajaran Outdoor.

Penerapan pembelajaran Outdoor akan mempengaruhi perilaku peserta didik menjadi lebih peduli terhadap lingkungan yang merupakan bagian tindakan yang dihasilkan dari pengetahuan yang salah satunya berasal dari pembelajaran. Berawal dari pengetahuan maka tertanamlah sikap peserta didik yang peduli lingkungan yang dipraktikan melalui suatu perilaku yang peduli lingkungan yang semua itu pada dasarnya merupakan tujuan dari pembelajaran pembangunan berkelanjutan dalam pelestarian lingkungan.

\section{METODE}

Penelitian eksperimen pendidikan merupakan kegiatan penelitian yang bertujuan untuk menilai pengaruh suatu perlakuan/tindakan/treatment pendidikan terhadap tingkah laku siswa atau menguji hipotesis tentang ada tidaknya pengaruh tindakan itu bila dibandingkan dengan tindakan lain. Penelitian ini menggunakan rancangan penelitian kuasi eksperimen dengan desain penelitian "Control Group". Pada dasarnya Rancangan yang digunakan dalam penelitian ini adalah desain kuasi eksperimen, jenis tes awal dan tes akhir pada kelas kontrol ekuivalen (homogen). Jadi, satu kelompok yang sama suatu ketika dijadikan sebagai group eksperimen (perlakuan) dan kelompok lain group kontrol. Desain ini menggunakan pre test yang diberikan sebelum perlakuan. Setelah diberi 
perlakuan, peserta didik diberikan post test untuk mengetahui apakah perlakuan yang diberikan menyebabkan perubahan yang lebih baik. Sehingga besarnya efek dari eksperimen dapat diketahui dengan pasti dengan cara membandingkan dengan kelompok kontrol.

Penelitian ini akan membandingkan hasil belajar sebelum diberi stimulus dan sesudah diberi stimulus pada kelompok kontrol dan perlakuan. Meskipun desain ini memiliki kelemahan bila waktu post test dan pre test terlalu jauh jaraknya maka tidak akan dapat memperoleh perbedaan antara sebelum dan sesudah perlakuan. Tetapi bila dilakukan dengan waktu yang sangat singkat mungkin dapat menghilangkan faktor waktu tersebut, tapi muncul persoalan maturation, mengingat subjek penelitian dapat mengalami kelelahan. Jadi untuk mengatasi masalah tersebut adalah dengan melakukan kontrol terhadap kondisi lingkungan tersebut sehingga didapatkan hasil penelitian yang bisa dibandingkan antara sebelum dan sesudah perlakuan. Jadi oleh karena itu dalam rancangan perlakuaannya dilakukan dalam dua kali pertemuan untuk menghindari faktor yang tidak dapat dikontrol tersebut.

Desain yang digunakan dalam penelitian ini digambarkan dalam bentuk table 1 berikut.

\section{Tabel 1. Desain Penelitian}

\begin{tabular}{llll}
\hline Keterangan & Pre test & Variabel Bebas/Perlakuan & Post test \\
\hline Kelas Eksperimen & $\mathrm{O} 1$ & $\mathrm{X}$ & $\mathrm{O} 2$ \\
Kelas Kontrol & $\mathrm{O} 1$ & - & $\mathrm{O} 2$ \\
\hline
\end{tabular}

Keterangan:

$\begin{array}{ll}\mathrm{O} 1 & \text { : Pre test } \\ \mathrm{X} & \text { : Perlakuan } \\ \mathrm{O} 2 & \text { : Post test }\end{array}$

Penelitian ini merupakan penelitian kuantitatif sehingga analisis data yang digunakan untuk mengolah data dalam penelitian menggunakan metode statistik. Analisis statistik yang digunakan adalah analisis statistik deskriptif dan analisis statistik inferensial parametrik. Analisis statistik deskriptif digunakan untuk mendeskripsikan atau memberikan gambaran data dalam bentuk tabel dan grafik, dari nilai rata-rata agar dengan mudah memperoleh gambaran mengenai 
Agus Purnomo. Pengaruh Pembelajaran Outdoor Terhadap Pengetahuan,

Dan Sikap Pelestarian Lingkungan Mahasiswa S1 Pendidikan Geografi Universitas Kanjuruhan Malang

sifat (karateristik) obyek dari data tersebut.

Data gain score didapatkan dari selisih antara score post test dengan score pre test. Untuk mencari perbedaan distribusi mean antara kelas eksperimen dan control menggunakan uji independent sample test. Adapun tingkat signifikasi yang digunakan yaitu 5\%. Data score sikap langsung dianalisis menggunakan uji independent sample test untuk mencari perbedaan distribusi mean-nya. Penghitungan analisis data selanjutnya dapat diselesaikan dengan bantuan program SPSS 16.0 for Windows.

\section{HASIL DAN PEMBAHASAN}

\section{Pengaruh Penerapan Pembelajaran}

\section{Out Door terhadap Pengetahuan}

\section{Pelestarian Lingkungan}

Pembelajaran outdoor juga termasuk pembelajaran yang bermakna ketika mampu mengaitkan pengetahuan dan nilai. Karena menurut Samani (2007) apapun pendekatan pembelajarannya, maka harus bermakna (meaningfull learning). Pembelajaran yang bermakna akan meningkatkan minat dan motivasi belajar peserta didik. NAAEE (2001) menyatakan bahwa dalam pembelajaran pendidikan lingkungan di luar kelas, peserta didik berhadapan secara langsung dengan obyek. Keadaan ini membawa peserta didik pada situasi konkret dan memberi dampak peningkatan apresiasi siswa terhadap konsep-konsep sains dan lingkungan yang diajarkan.

Karakteristik pembelajaran outdoor yang mengahadapkan langsung peserta didik dengan masalah yang ada di lingkungan sekitar mereka membuatnya bermakna. Selain itu juga masalah memberikan peluang untuk meningkatkan motivasi dalam diri peserta didik (Amir, 2010). Hal ini dapat dilihat dari motivasi belajarnya untuk terus menambah pengetahuan pelestarian lingkungan baik dari buku maupun mengikuti seminar yang tinggi.

$$
\text { Krynock dan Robb }
$$
menyatakan bahwa siswa yang merasa pelajarannya relevan dengan kehidupan akan memiliki motivasi yang tinggi dalam belajar. Pembelajaran outdoor memberikan peserta didik pengetahuan yang relevan karena memanfaatkan alam sekitar sebagai media pembelajaran. Pemanfaatan alam sekiar memiliki 
beberapa keunggulan, yaitu murah dan dikenal peserta didik secara pedagogis.

Bloom (Anderson dan Krathwohl, 2001) menyatakan bahwa lingkungan di luar kelas dapat membawa peserta didik pada situasi yang lebih konkret dan memberikan dampak peningkatan apresiasi mereka terhadap konsep-konsep yang diajarkan. Selain itu, pembelajaran di luar kelas dapat menumbuhkan keinginan untuk belajar. Studi yang dilakukan SEER menemukan bahwa antusiasme dan keinginan siswa untuk belajar meningkat dalam setiap sekolah yang menerapkan pembelajaran di luar kelas (NAAEE, 2001).

Pelaksanaan pembelajaran outdoor telah ditemukan keunggulan dan keterbatasannya. Keunggulan dan keterbatasan dalam model pembelajaran ini terungkap dari hasil observasi pelaksanaan pembelajaran, hasil belajar, dan sikap peserta didik terhadap pelestarian lingkungan hidup. Keunggulan dari pembelajaran terkait dengan (1) Meningkatkan penguasaan konsep tantangan pengembangan wilayah yang berkelanjutan terutama pada permasalahan lingkungan, (2) Dapat menghubungkan kemampuan awal peserta didik dengan struktur kognitif yang baru dengan memanfaatkan lingkungan sekolah sebagai sumber belajar, (3) Dapat meningkatkan motivasi belajar peserta didik karena menghadapkan mereka langsung dengan permasalahan lingkungan yang ada di sekitar mereka. Keterbatasannya berkaitan dengan kendala yang dialami selama pelaksanaan antara lain (1) Perlu adanya perancangan materi pengantar yang baik yang menjadi bekal pengatahuan peserta didik dalam mengobservasi ketika pelaksanaan pembelajaran outdoor dan (2) Perlu materi pengantar dengan komposisi konsep konkit yang lebih banyak dari pada konsep abstrak, karena peserta didik lebih mudah memahami konsep kontrit dari pada konsep abstrak.

Temuan tambahan yang didapatkan dari hasil observasi selama pembelajaran outdoor dalam penelitian ini bahwa diperlukan modul sebagai pembimbing peserta didik dalam melakukan observasi langsung di lapangan. Seperti pada penelitian yang dilakukan oleh Popov (2007) ditemukan bahwa selama kegiatan outdoor berlangsung peserta didik kurang mampu mengkomunikasikan fenomena yang telah diamati selama pembelajaran berlangsung. Hal ini mungkin disebabkan karena mereka tidak diberi modul yang digunakan sebagai pembimbing. Berbeda 
Agus Purnomo. Pengaruh Pembelajaran Outdoor Terhadap Pengetahuan,

Dan Sikap Pelestarian Lingkungan Mahasiswa S1 Pendidikan Geografi Universitas Kanjuruhan Malang

dengan penelitian yang telah dilakukan peneliti, mereka diberi modul kontekstual yang digunakan sebagai pembimbing ketika kegiatan outdoor berlangsung, sehingga lebih mampu mengkomunikasikan fenomena yang diamati.

Jadi dari hasil pembahasan di atas mendukung pendapat Johnson (1991) yang menyatakan bahwa tujuan pertama dari pembelajaran outdoor untuk merubah struktur kognitif atau pengetahuan peserta didik. Perubahan pengetahuan yang mereka dapatkan akan berpengaruh pada perubahan sikap dan perilakunya.

\section{Pengaruh Penerapan Pembelajaran}

\section{Outdoor terhadap Pengetahuan}

\section{Pelestarian Lingkungan}

Keterkaitan antara sikap peduli terhadap lingkungan dengan pengetahuan tentang lingkungan hidup didukung oleh hasil penelitian Rampengan (2005) yang menemukan bahwa pemahaman tentang materi pendidikan lingkungan dapat mempengaruhi sikap terhadap lingkungan. Hal yang sama dikemukakan Srimulyani (2000) bahwa sikap positif terhadap pengelolaan lingkungan hidup didukung oleh pengetahuan tentang lingkungan hidup yang relatif baik. Mastrilli (2005) dalam penelitiannya juga menemukan bahwa terdapat hubungan positif antara pengetahuan lingkungan hidup dengan sikap dan minat guru terhadap pengelolaan lingkungan hidup.

Pengukuran sikap pelestarian lingkungan hidup peserta didik menggunakan angket. Dari hasil angket sebagian besar peserta didik pada kelas eksperimen cenderung lebih bersikap positif setelah mendapatkan pembelajaran lingkungan berbasis out door dalam perkuliahannya. Hal ini sesuai dengan pendapat Wilson dan Tomera (dalam Coyle, 2004) yang menyatakan penambahan aktivitas yang berbasis lingkungan ke dalam perkuliahan dapat menimbulkan perubahan sikap terhadap lingkungan secara signifikan. Suchman (dalam Joyce, 2000) menyatakan bahwa pendidikan lingkungan dimulai dengan menyajikan peristiwa alam yang penuh masalah. Jika mereka dihadapkan dengan situasi yang bermasalah, dapat menimbulkan motivasi untuk menyelesaikan masalah tersebut.

Dari hasil wawancara dengan beberapa peserta didik, didapatkan 
kesimpulan bahwa faktor lingkungan sekitar tempat mereka tinggal ternyata tidak memungkinkan melakukan kegiatan untuk mendukung menjaga kebersihan lingkungan. Seperti dalam pengelolaan sampah, pemilahan sampah organik dan anorganik akan mempermudah proses pengolahan sampah selanjutnya, tetapi karena tidak ada tempat pengolahan sampah untuk proses selanjutnya warga hanya menyerahkan tugas membersihkan lingkungan pada tukang sampah dan terkadang ada beberapa warga hanya membuangnya langsung ke sungai. Sehingga meskipun mereka mengetahui cara yang benar dalam mengelola sampah, mereka tidak dapat melakukannya karena hanya warga pendatang. Dugaan ini diperkuat dengan pernyataan Sumarni (2009) bahwa terdapat konsistensi dan inkonsistensi antara sikap dan pengetahuan dikarenakan faktor eksternal yang berpengaruh. Krench (dalam Rustaman, 2010) yang menyatakan faktor yang berpengaruh dalam pengubahan sikap tergantung pada keinginan individu, kepribadian, kerja kelompok, dan lingkungan yang mendukung.

HSF (2008) menyatakan bahwa kesadaran manusia terhadap lingkungan hidup akan terbangun dengan baik apabila pendidikan lingkungan hidup telah diberikan kepada mereka, baik melalui jalur pendidikan formal, non formal, maupun informal. Kesadaran yang terbangun memalui pembelajaran outdoor menunjukkan bahwa seluruh peserta didik menunjukkan sikap yang sangat peduli terhadap pelestarian lingkungan. Hal ini menunjukkan bahwa pembelajaran ini memiliki pengaruh yang sangat signifikan terhadap sikap pelestarian lingkungan hidup. HessQuimbita (1996) mengemukakan bahwa kuliah sains mempunyai peranan penting dalam mengembangkan sikap positif terhadap lingkungan.

Thompson (1994) menyatakan bahwa peserta didik yang memandang belajar sebagai sesuatu yang bermanfaat, ia bersikap positif terhadap belajar, dan sebaliknya peserta didik yang memandang belajar sebagai sesuatu yang tidak berguna, dia bersikap negatif terhadap pelajaran. Dumouchel (2003) menyatakan bahwa pendidikan outdoor dapat meningkatkan kesadaran siswa terhadap alam melalui pengamatan langsung.

Pentingnya tentang sikap yang positif terhadap lingkungan juga didukung oleh penelitian Powers (2004) yang menyatakan bahwa sebagian besar 
Agus Purnomo. Pengaruh Pembelajaran Outdoor Terhadap Pengetahuan,

Dan Sikap Pelestarian Lingkungan Mahasiswa S1 Pendidikan Geografi Universitas Kanjuruhan Malang

responden $(78 \%)$ setuju dan sangat setuju bila seluruh peserta didik disiapkan dengan memasukkan pendidikan lingkungan ke dalam pembelajaran dan pendidikan lingkungan menjadi bagian yang penting dalam. Pembelajaran outdoor mempunyai karakteristik dapat menanamkan sikap peduli terhadap lingkungan. Davidoff (1994) menyatakan lembaga pendidikan merupakan miniatur masyarakat. Nilai-nilai yang diperoleh peserta didik terbawa dan tercermin dalam kehidupan sehari-hari pendidik mempunyai peranan yang besar dalam membentuk perilaku mereka. Bandura (1977) menyatakan bahwa sikap sebagai ekspresi dari nilai atau pandangan hidup seseorang, dapat dibentuk menjadi perilaku atau tindakan yang diinginkan, yaitu perilaku peduli lingkungan.

\section{KESIMPULAN}

Berdasarkan pada fokus masalah serta temuan penelitian yang didasarkan pada hasil analisis, maka kesimpulan yang dapat dikemukakan dalam penelitian ini adalah pengetahuan pelestarian lingkungan perserta didik kelas eksperimen setelah mendapatkan perlakuan dengan menggunakan pembelajaran out door lebih baik dibandingkan dengan pembelajaran konvensional. Dengan demikian perlakuan pada kelas eksperimen dengan menggunakan Pembelajaran berbasis Out Door berpengaruh signifikan terhadap pengetahuan pelestarian lingkungan perserta didik. Dan sikap pelestarian lingkungan perserta didik kelas eksperimen setelah mendapatkan perlakuan dengan menggunakan pembelajaran out door lebih baik dibandingkan dengan pembelajaran konvensional. Dengan demikian perlakuan pada kelas eksperimen dengan menggunakan Pembelajaran berbasis Out Door berpengaruh signifikan terhadap sikap pelestarian lingkungan perserta didik.

\section{DAFTAR PUSTAKA}

American Institutes for Research. 2005. Effects of Outdoor Education Programs for Children in California. Sacramento: The California Department of Education.

Amir, M. Taufik. 2010. Inovasi Pendidikan Melalui Problem Based Learning. Jakarta: Kencana.

Amini, Risda. 2010. Pengembangan Pembelajaran Pendidikan Lingkungan Berbasis Outdoor Untuk Calon Guru Sekolah Dasar. 
Disertasi Pascasarjana UPI. Bandung (tidak diterbitkan).

Bandura, A. 1977. Social Learning Theory. New Yersey: Prince-Hall.

Davidoff, L. L. 1991. Psikologi: Suatu Pengantar. (Jilid 1, Edisi kedua). Jakarta: Erlangga.

Dumouchel. 2003.New Horizons for Learning. (Online). Diakses di http://www.newhorizons.org pada tanggal 18 Maret 2015.

Hess-Quimbita, G. \& Michael, P. (1996). Assessing an Environmental Attitude Development Program: Factors Influencing the Environmental Attitude of College Students. Paper presented at the American Education Research Association Conference. April 812, 1996. New York.

HSF (Hanns Seidel Foundation). (2008).Pendidikan Lingkungan Hidup Terkait dengan Air dan Tanah. (online). Diakses di www.hsfindo.org pada tanggal tanggal 18 Maret 2015.

Johnson. David. W dan Johnson. Frank. P. 1991. Joining Together: group theory and group skills. Prentice Hall

Herry, F. 2009. Outdoor Learning antara Hobi dan Bisnis. (Online). Diakses di

http://pioda.multiply.com/reviewspa da tanggal 18 Maret 2015

Krynock, K. and L. Robb. (1999). Problem Solved: How to Coach
Cognition. Educational Leadership, 57(3), p. 29-32.

Mastrilli, T. (2005). Environmental Education in Pennsylavania's Elementary Teacher Preparation Program:The Fight to Legitimize EE.Journal of Environmental Education. September 2005. New England.

Powers, A. L. (2004). Teacher Preparation for Environmental Education: Faculty Perspective on the Infusion of Environmental Education into Preservice Methods Courses. Journal of Environmental Education, Spring Vol.35 No.3. p. 3-11.

Rampengan, M. J. (2005). Pemahaman Konsep-konsep Dasar Ekologi dan Sikap Masyarakat Petani Sekitar Danau Tondano Terhadap Kerusakan Lingkungan serta Implikasinya pada Pendidikan IPA. Studi Kasus di Kecamatan Eris Kabupaten Minahasa. Disertasi Pascasarjana UPI. Bandung (tidak diterbitkan)

Anthropocentric Attitudes Toward the Environment. Journal of Environment Psychology. p. 14-33.

Tumisem. 2007. Program Pendidikan Lingkungan Berbasis Ekologi Perairan sebagai Upaya Pengembangan Literasi Lingkungan dan Konservasi melalui Kepramukaan di SD. Disertasi Pascasarjana UPI. Bandung (tidak diterbitkan). 